JHR

36,5

794

Received 19 September 2020 Revised 22 October 2020 Accepted 4 December 2020

\section{Perceptions, knowledge and self-defense behaviors regarding COVID-19 among employees at Rajamangala University of Technology Thanyaburi, Thailand}

\author{
Issara Siramaneerat \\ Department of Social Science, \\ Faculty of Liberal Art, Rajamangala University of Technology Thanyaburi, \\ Pathum Thani, Thailand
}

\begin{abstract}
Purpose - This research aims to study self-defense behaviors from coronavirus disease 2019 (COVID-19) and to investigate factors affecting the prevention and control behavior of COVID-19 among personnel at Rajamangala University of Technology Thanyaburi.

Design/methodology/approach - The sample was 405 personnel of Rajamangala University of Technology Thanyaburi. The sample was calculated by using the Yamane formula at a confidence level of 95. The researcher collected the data between July 1 and 15, 2020. Questionnaire items were developed following the health belief model (HBM). The questionnaire contains basic information, knowledge of COVID-19, perception of COVID-19 and COVID-19 preventive behaviors. Data were analyzed by descriptive statistics, correlation coefficients and multiple regression analysis at the statistical significance level of 0.05 .

Findings - The results showed that the sample had an average knowledge about COVID-19 of 8.93, the perceived of risk and severity of COVID-19 was presented average of 4.22 and 3.48. The perceived of benefits and barriers of COVID-19 showed average of 4.31 and 2.72 and mean of COVID-19 prevention and control behaviors was 2.41. The multiple regression analysis showed that the model can explain the various self-defense behaviors from COVID-19 of $11.30 \%$. Perception of the benefits of COVID-19 had a statistically significant effect on self-defense behaviors from COVID-19 at the level 0.05 (Beta $=0.232,95 \%$ CI: $1.233-3.395, p<0.001)$.
\end{abstract}

Originality/value - Based on the results, the relationship between HBM and COVID-19 prevention behavior can be clearly seen. This study found the perception of benefit toward COVID-19 affected prevention practice. Thus, using HBM could be useful in improving preventive behaviors of COVID-19.

Keywords Perception of benefit, Self-defense behavior, COVID-19

Paper type Research paper

\section{Introduction}

Coronavirus was first discovered in the 1960s as a virus that could infect both humans and animals. A total of six strains of this virus have now been identified, but among the strains that are currently known, a previously unknown strain, the seventh strain, is now referred to as the first virus. This was named the "New coronavirus" and later formally named

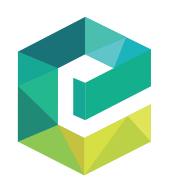

(C) Issara Siramaneerat. Published in Journal of Health Research. Published by Emerald Publishing Limited. This article is published under the Creative Commons Attribution (CC BY 4.0) licence. Anyone may reproduce, distribute, translate and create derivative works of this article (for both commercial and non-commercial purposes), subject to full attribution to the original publication and authors. The full terms of this licence may be seen at http://creativecommons.org/licences/by/4.0/legalcode

This research was funded by the research promotion fund of the Research and Development Institute of Rajamangala University of Technology Thanyaburi in the annual fiscal year 2020, Contract No. COVID63D911. 
coronavirus disease 2019 "COVID-19". The World Health Organization (WHO) stated that symptoms of COVID-19 are easily observed and include fever, sore throat, dry cough, runny nose and shortness of breath [1]. However, some cases experience complications such as pneumonia which may be examined with a lung X-ray. If the symptoms are very severe, they can lead to internal organ failure and can be fatal. As this virus is a new strain, there is currently no antibiotic that can directly cure patients. Treatment is palliative only with symptoms [1, 2]. In addition, the danger can be life-threatening when the immune system is not healthy as the virus can destroy the lung function. As a result, the virus spreads more rapidly through aerosol from the respiratory system of the patient when the patient coughs or sneezes. A person's risk of contracting COVID-19 is high. However, many people with COVID-19 have mild symptoms, especially in the early stages. Therefore, it is possible to be infected by a patient who has a mild cough or experiences little discomfort $[1,2]$.

In Thailand, the coronavirus outbreak began on January 13,2020, with the first confirmed case from China. The government's response to the outbreak began with screening and monitoring exposure. COVID-19 was screened at international airports as well as at hospitals for patients with a history of travel or exposure [3]. Currently, the Department of Disease Control, Ministry of Public Health reported that as of October 19, 2020, the number of new infections has increased continually, bringing the cumulative number of confirmed cases to 3,691, including 59 deaths and 144 still hospitalized [4]. The Ministry of Public Health has assessed the risks that may spread to Thailand to plan for future preparedness. In addition, important deterrent and preventive measures are in place to educate people on screening, selfdefense, as well as surveillance in conjunction with infected people searches and publicizing proactive education on the subject to local residents [5].

Rajamangala University of Technology Thanyaburi (RMUTT), a leading technological university in Thailand is ranked among the top 25 in Association of Southeast Asian Nations (ASEAN)'s technological universities. Currently, RMUTT has a total of 19,480 students [6]. The study of COVID-19 prevention behaviors among university employees is essential because these personnel are in contact with students from different regions, the results of which will be preliminary to the agency and will also help to prepare a policy to prevent the spread of the disease in time.

This research aimed to study COVID-19 prevention and control behaviors by applying the health belief model (HBM) [7] that is used to describe a person's behavior. A person's perception of a situation is an indicator of healthy behavior. The way people approach or do what they please depend on whether they think that something would be good for them. The person then shifts from the things they do not like that may cause harm to their health. Health belief patterns were developed, analyzing the behavior and decisions of individuals when they were at risk of disease [7]. According to a previous study, it was found that a lack of proper knowledge about disease was associated with negative emotions among people, which could complicate efforts to prevent the spread of the disease [8-10]. There is high uncertainty about the potential severity and the ability to control the process by prophylactic. In addition, in previous studies, preventive behaviors for respiratory infections such as severe acute respiratory syndrome (SARS) and H1N1 were affected by the level of knowledge and perception, benefits and barriers to action [11-13], and perception of risk toward disease [11,13].

However, previous studies did not identify if the five variables of knowledge, perception of risk, perception of severity, perception of benefits and perception of barriers were correlated with preventive behavior against COVID-19 disease. Therefore, understanding the COVID-19 prevention and control behavior model will provide the root cause and systematic management of COVID-19 prevention and control. It would also help to analyze the factors for consideration in order to decide to act on that behavior [7, 14]. The research results reflect the level of COVID-19 prevention and control behaviors among employees at RMUTT, in order to use the information to support universities and related agencies in developing COVID-19
Perceptions, knowledge and self-defense behaviors

795 
JHR 36,5

796

prevention and control measures or adjusting their implementation, and optimize work by sharing feedback with policymakers for more effective solutions in this situation.

\section{Methods}

The study population in this research were staff members employed at RMUTT making up a total of 2,167 people [15]. The sample used in this study was 405 employees at the university using the formula for calculating the sampling group of Yamane with a 95\% confidence level [16]. The calculated sample size was 399.98 samples. We added another five sample collection cases to prevent possible mistakes. Therefore, in this research, there were a total of 405 cases. A sample size based on the criteria and all personnel in RMUTT were given the opportunity to respond to the questionnaire so that it should lead to more accurate or representative results.

The inclusion criteria were those who worked in RMUTT and were willing to answer the questionnaire. The exclusion criteria were those who were employed at the university on temporary contracts.

Multistage sampling selection was used to select the data as follows:

Step 1: The researcher performed the quota sampling by searching for the proportion of personnel classified by the faculty and office, divided into 31 departments.

Step 2: The researcher collected a total of 405 people using convenient sampling, distributing questionnaires through Google Forms until obtaining the number of samples according to the specified quota.

The tool used in this research was a questionnaire divided into four parts: Part 1 included questions about basic information such as gender, age, education level, marital status, position, length of work, monthly income expenses per month, number of family members, smoking and alcohol behavior, and health condition. Part 2 included 10 questions assessing knowledge of COVID-19, 1 point was given in the case of correct answers, 0 points in the case of incorrect or unknown answers. Part 3 included questions about the perception of COVID-19 which the researcher adapted from the concept of the HBM [7, 14]. This section was divided into four areas: perception of risk toward COVID-19, perception of severity toward COVID-19, perception of benefit toward COVID-19 and the perception of barriers to action toward COVID-19. Characteristics of questionnaires used as rating scale questionnaires were divided into five levels (Total of 20 items, 5 items on each side). Part 4 included 15 questions on COVID-19 prevention and control behaviors. Answers in this section were coded 0 for "never practice", 1 for "practice seldom", 2 for "practice often," and 3 for "practice regularly".

Index of item objective congruence was tested to measure the reliability of the questionnaire which had a value greater than 0.50 [17]. The researcher led the questionnaire which was revised according to the recommendations of experts. It was then trialed on a group of 30 people [17]. The reliability of the questionnaire was analyzed by Cronbach's alpha coefficient. The validity of the questionnaire was greater than 0.70 for the questionnaire to be used [17]. The difficulty of knowledge about COVID-19 was tested to measure effective results which had a difficulty value of $0.20-0.80$ [17]. The discrimination test of knowledge about COVID-19 presented discriminatory power higher than 0.2 which represented an exam with good identification power [17].

Data analysis included frequency, percentage, mean and standard deviation. Correlation coefficient was used to measure the strength of the relationship between the variables. Analysis of the impact of knowledge and perceptions of COVID-19 toward prevention and control behavior related to COVID-19 of personnel of RMUTT was calculated by multiple regression analysis with statistical significance at 0.05 . 
Ethical issue

This study was approved by the Review Boards of the Ethical Committee of RMUTT (COA No.13 RMUTT_REC No. Full 13/63).

\section{Results}

Results of the personal analysis of respondents found that the majority (254) of participants were women $(62.7 \%)$, the average age was 41.02 years $(\mathrm{SD}=9.18)$, most of them $(202$ participants) were married, accounting for $49.9 \%$ of participants and 173 participants had a master's degree making up $42.8 \%$. The working status was mainly support academic staff at the university numbering 184 people (45.4\%). Most (141 participants) of them had worked for more than 15 years, representing $34.8 \%$. The majority had a monthly income of 20,00130,000 baht accounting for $31.4 \%$. Most of them had living expenses per month of 10,00120,000 baht (35.8\%). Most of them had 4 or more family members $(38.3 \%)$. The majority of the sample did not smoke $(92.6 \%)$, drinking alcohol accounted for $52.6 \%$ and the majority did not have a congenital disease $(64.0 \%)$.

Table 1 presents the average of knowledge toward COVID-19, perception toward COVID-19, and prevention and control behaviors related to COVID-19. The average of knowledge toward COVID-19 was 8.93 (SD = 1.54), the perception of risk, severity, benefit and barriers were $4.22,3.48,4.31$ and 2.72 , respectively. Moreover, the average for self-defense behaviors from COVID-19 was 2.41(SD = 0.44).

Regarding correlation analysis, knowledge of COVID-19, perception of risk, severity and benefit had a relationship with self-defense behaviors from COVID-19 $(r=0.140, r=0.237$, $r=0.129, r=0.308, p<.001$ ), as shown in Table 2 .

For multiple regression analysis, the model could explain the various self-defense behaviors from COVID-19 at $11.30 \%(r$-square $=0.113)$. The perception of benefit affected self-defense behaviors from COVID-19 and was at a statistically significant level of 0.05 (Beta $=0.232,95 \%$ CI: $1.233-3.395, p<0.001$ ) as shown in Table 3.

\begin{tabular}{lllr}
\hline Factor & Mean & SD \\
\hline Knowledge about COVID-19 & 8.93 & 1.54 & Table 1. \\
Perception of risk toward COVID-19 & 4.22 & 0.67 & 0.55 \\
Perception of severity toward COVID-19 & 3.478 & 0.66 & Mean and standard \\
Perception of benefits in COVID-19 prevention practices & 4.312 & 1.05 deviation of the studied \\
Perception of barriers to action toward COVID-19 prevention & 2.724 & $0.44 \quad$ variables $(n=405)$ \\
COVID-19 prevention and control behaviors & 2.41 & & \\
\hline
\end{tabular}

\begin{tabular}{|c|c|c|c|c|c|c|}
\hline Factor & 1 & 2 & 3 & 4 & 5 & 6 \\
\hline Knowledge about COVID-19 & 1 & & & & & \\
\hline Perception of risk toward COVID-19 & $0.183^{* *}$ & 1 & & & & \\
\hline Perception of severity toward COVID-19 & $0.125^{*}$ & $0.293^{* *}$ & 1 & & & \\
\hline $\begin{array}{l}\text { Perception of benefits in COVID-19 prevention } \\
\text { practices }\end{array}$ & $0.196^{* *}$ & $0.484 * *$ & $0.277 * *$ & 1 & & \\
\hline $\begin{array}{l}\text { Perception of barriers to action toward COVID- } \\
19 \text { prevention }\end{array}$ & $-0.161^{* *}$ & 0.060 & $0.198^{* *}$ & -0.041 & 1 & \\
\hline COVID-19 prevention and control behaviors & $0.140 * *$ & $0.237 * *$ & $0.129 * *$ & $0.308 * *$ & -0.060 & 1 \\
\hline
\end{tabular}

Note(s): $* p<0.05, * * p<0.01$ correlation coefficients between the studied variables $(n=405)$ 


\begin{tabular}{|c|c|c|c|c|c|c|c|c|}
\hline \multirow[t]{2}{*}{$\begin{array}{l}\mathrm{JHR} \\
36,5\end{array}$} & & \multicolumn{2}{|c|}{$\begin{array}{c}\text { Unstandardized } \\
\text { coefficients } \\
\text { Std. }\end{array}$} & \multicolumn{3}{|l|}{$\begin{array}{l}\text { Standardized } \\
\text { coefficients }\end{array}$} & \multicolumn{2}{|c|}{$\begin{array}{l}95.0 \% \text { confidence } \\
\text { interval for B }\end{array}$} \\
\hline & & $B$ & $\begin{array}{l}\text { Std. } \\
\text { Error }\end{array}$ & Beta & $T$ & Sig & $\begin{array}{l}\text { Lower } \\
\text { bound }\end{array}$ & $\begin{array}{l}\text { Upper } \\
\text { bound }\end{array}$ \\
\hline \multirow[b]{2}{*}{798} & (Constant) & 18.928 & 3.029 & & 6.248 & 0.000 & 12.973 & 24.884 \\
\hline & $\begin{array}{l}\text { Knowledge about } \\
\text { COVID-19 }\end{array}$ & 0.262 & 0.210 & 0.062 & 1.250 & 0.212 & -0.150 & 0.674 \\
\hline & $\begin{array}{l}\text { Perception of risk } \\
\text { toward COVID-19 }\end{array}$ & 1.039 & 0.541 & 0.106 & 1.921 & 0.055 & -0.024 & 2.103 \\
\hline \multirow{4}{*}{$\begin{array}{l}\text { Table } 3 \text {. } \\
\text { Multiple regression } \\
\text { analysis of factors } \\
\text { affecting self-defense } \\
\text { behaviors from } \\
\text { COVID-19 } \\
\text { behavior }(n=405)\end{array}$} & $\begin{array}{l}\text { Perception of severity } \\
\text { toward COVID-19 }\end{array}$ & 0.432 & 0.611 & 0.036 & 0.707 & 0.480 & -0.769 & 1.633 \\
\hline & $\begin{array}{l}\text { Perception of benefits in } \\
\text { COVID-19 prevention } \\
\text { practices }\end{array}$ & 2.314 & 0.550 & 0.232 & $4.209 *$ & 0.000 & 1.233 & 3.395 \\
\hline & $\begin{array}{l}\text { Perception of barriers to } \\
\text { action toward COVID-19 }\end{array}$ & -0.337 & 0.308 & -0.054 & -1.093 & 0.275 & -0.943 & 0.269 \\
\hline & \multicolumn{8}{|c|}{$\begin{array}{l}\text { Note(s): } * p<0.05, * * p<0.01 \\
R=0.337, r \text {-square }=0.113 \text {, std. error of the estimate }=6.210, F \text { change }=10.193\end{array}$} \\
\hline
\end{tabular}

From the analysis of the correlation in Table 2 and multiple regression analysis in Table 3 , it can be seen that the correlation analysis found four factors with statistically significant differences: the knowledge toward COVID-19, the perception of risk toward COVID-19, the perception of severity toward COVID-19 and the perception of benefit toward COVID-19. But when all variables in the equation were controlled, it was found that only the perception of benefit toward COVID-19 affected self-defense behaviors from COVID-19.

\section{Discussion}

At the time of publication, more than 32.7 million COVID-19 cases and 991,000 deaths were reported. The WHO reports that during the week of September 21-27, 2020, more than two million new cases and 36,000 new deaths were reported [18]. The Ministry of Health of Thailand has reported more than 3,709 COVID-19 cases since the first case was reported on January 13, 2020, and 59 had died in Thailand [4]. The results showed that the perceived benefit of COVID-19 awareness affected COVID-19 self-defense behaviors. Therefore, being aware of COVID-19 is a good epidemic countermeasures and results in self-defense behaviors. Perceived benefits in the HBM model were defined as an assessment of the value or effectiveness of individuals participating in health-promoting behaviors to reduce disease risk $[7,14]$. If a person believes that a specific action will reduce their susceptibility to a health problem or reduce the seriousness of the problem, then he or she is more likely to engage in that behavior regardless of the objective facts about the effectiveness of the problem. The perceived benefit must outweigh the perceived barriers for behavior change to take place [19-21].

Therefore, the decision to follow the advice is based on a comparison of the pros and cons of that behavior. By discriminating between what is better over what is bad is consistent with the theory of health beliefs [7, 14] and the concept, model, process of health action [22] stated that the person seeking a way to act and recover from disease or prevent disease.

Therefore, those who have perception of disease prevention benefit from safe practices tend to adjust their lifestyles in order to practice appropriate health behaviors such as exercising, reducing fat intake, increasing fiber intake, etc. [23, 24]. People will seek ways to follow preventive and rehabilitation recommendations as long as prophylactic practices are more positive than the occurrence of the disease. By following prevention instructions, the 
sense of fear or threat of disease occurrence can be overcome through knowledge of how to prevent the disease from affecting them [25, 26]. Without any obstacles, psychological aspects are involved such as costs, inconvenience, illness, embarrassment, etc. [27]. Anuruk [28] stated that the practice or expression of a person to act or refrain from acting has an effect on health by learning an appropriate understanding of related health practices, including preventive behaviors.

COVID-19 has a higher transmission rate than previous coronaviruses and affects many organs. Lack of awareness of population infection control will lead to the rapid spread of the disease around the world [29, 30]. Additionally, psychological elements such as fearful behavior, misinformation and economic worries will place great pressure on populations limiting the implementation of these government measures, thereby increasing the effects of the COVID-19 epidemic indirectly [26].

\section{Conclusion}

The results showed that the majority of personnel had high level of COVID-19 prevention knowledge and control behaviors. Moreover, research results showed that enhancing the perception of benefit in COVID-19 prevention practices would improve COVID-19 prevention behaviors and would further improve with COVID-19 prevention guidelines.

Conflicts of Interest: None

\section{References}

1. Woratanarat T. Corona Virus 2019 (COVID-19): what do we know now?. [updated 2020 Feb 2; cited 2020 Aug 2]. Available from: https://www.hfocus.org/print/18552.

2. Ministry of Public Health, Department of Disease Control. Corona virus infectious disease 2019 (COVID-19). [cited 2020 Aug 2]. Available from: https://ddc.moph.go.th/viralpneumonia/info.php.

3. The Standard Team. Prime Minister declares state of emergency effective 26 March in response to COVID-19; maintains there is no curfew yet. [updated 2020 Mar 24; cited 2020 Aug 2]. Available from: https://thestandard.co/promulgating-the-emergency-decree/.

4. Cheung E. Wuhan pneumonia: Thailand confirms first case of virus outside China. [updated 2020 Jan 13; cited 2020 Aug 2]. Available from: https://sg.news.yahoo.com/wuhan-pneumonia-thailandconfirms-first-123311706.html.

5. Ministry of Public Health, Department of Disease Control. Situation report coronavirus disease 2019 (COVID-19) (both domestic and worldwide) media, knowledge, advice and operational guidelines for agencies / related persons/public. [cited 2020 Aug 7]. Available from: https://ddc. moph.go.th/viralpneumonia/.

6. Rajamangala University of Technology Thanyaburi, Office of academic promotion and registration. Thanyaburi: General information of Rajamangala University of Technology. [cited 2020 Aug 2]. Available from: https://www.ped.rmutt.ac.th/.

7. Rosenstock IM. Historical origins of the health belief model. Health Educ Monogr. 1974; 2(4): $328-35$

8. Ilesanmi O, Alele FO. Knowledge, attitude and perception of ebola virus disease among secondary school students in Ondo State, Nigeria, October, 2014. PLoS Curr. 2016; 8. doi: 10.1371/currents. outbreaks.c04b88cd5cd03cccb99e125657eecd76.

9. Wong LP, Sam IC. Knowledge and attitudes in regard to pandemic influenza $A(H 1 N 1)$ in a multiethnic community of Malaysia. Int J Behav Med. 2011; 18(2): 112-21. doi: 10.1007/s12529-0109114-9. 
JHR

36,5
10. Lau JT, Kim JH, Tsui H, Griffiths S. Perceptions related to human avian influenza and their associations with anticipated psychological and behavioral responses at the onset of outbreak in the Hong Kong Chinese general population. Am J Infect Control. 2007; 35(1): 38-49. doi: 10.1016/j. ajic.2006.07.010.

11. Brug J, Aro AR, Oenema A, de Zwart O, Richardus JH, Bishop GD. SARS risk perception, knowledge, precautions, and information sources, The Netherlands. Emerg Infect Dis. 2004; 10(8): 1486-9. doi: 10.3201/eid1008.040283.

12. Choi JS, Yang NY. Perceived knowledge, attitude, and compliance with preventive behavior on influenza A (H1N1) by university students. J Korean Acad Adult Nurs. 2010; 22(3): 250-9.

13. Hussain ZA, Hussain SA, Hussain FA. Medical students' knowledge, perceptions, and behavioral intentions towards the H1N1 influenza, swine flu, in Pakistan: a brief report. Am J Infect Control. 2012; 40(3): e11-3. doi: 10.1016/j.ajic.2011.12.004.

14. Becker MH. The health belief model and personal health behavior. New Jersey: Charles B. Slack; 1974.

15. Rajamangala University of Technology Thanyaburi, Division of personnel management. Personnel report about Rajamangala university of Technology Thanyaburi. [updated 2020 Apr; cited 2020 Aug 2]. Available from: https://www.ped.rmutt.ac.th/?p=7551.

16. Yamane T. Statistics: an introductory analysis. 3rd ed. New York, NY: Harper and Row; 1973.

17. Vanichbancha K. Statistical analysis: statistics for administration and research. Bangkok: Chulalongkorn University Press; 2007.

18. World Health Organization [WHO]. Coronavirus disease (COVID-19), data as received by WHO from national authorities, as of 27 September 2020. [updated 2020 Sep 28; cited 2020 Oct 20]. Available from: https://www.who.int/publications/m/item/weekly-epidemiological-update-28-september-2020.

19. Rattanamanee K, Khamngoen R, Saetew P. Knowledge, attitudes, and practices on the prevention and control of pandemic influenza type A H1N1 2009 among teachers child care providers in nurseries located in Surat Thani province. Nursing Journal of the Ministry of Public Health. 2013; 22(3): 26-38.

20. Issarungkoon Na Ayuttaya C. Health education operation process model for avian influenza prevention behavior development. Bangkok: Chulalongkorn University; 2008.

21. Rakitti W. Principles of health education. (Teaching document of public health academic, Series 2). Nonthaburi: Sukhothai Thammathirat Open University; 1993.

22. Suphanthas S. Behavior and transformation. (Teaching document of public health academic Series 1, Unit 1). 14th ed. Nonthaburi: Sukhothai Thammathirat Open University; 1997.

23. Noorak S. Prevention behavior of non-insulin diabetes patients at the diabetes clinic. Bangkok: Srinakharinwirot University; 2003.

24. Jain N, Mitra D, Ashok KP, Dundappa J, Soni S, Ahmed S. Oral hygiene-awareness and practice among patients attending OPD at Vyas dental college and hospital, Jodhpur. J Indian Soc Periodontol. 2012 Oct; 16(4): 524-8. doi: 10.4103/0972-124x.106894.

25. Orem DE. Nursing: concepts of practice. 2nd ed. New York, NY: McGraw-Hill; 1979.

26. Janz NK, Champion VL, Strecher VJ. The health belief model. In: Glanz K, Lewis FM, Rimer BK, editors. Health behavior and health education: theory, research and practice. 3rd ed. San Francisco: Jossey-Bass; 2002. p. 47-50.

27. Schwarzer R. Optimism, vulnerability, and self-beliefs as health-related cognitions: a systematic overview. Psychol Health. 1994; 9(3): 161-80.

28. Anuruk Y. Health education process and health behavior development 2000. Bangkok: Sigma Graphic Design; 2000.

29. Bischof E, Chen G, Ferretti MT. Understanding COVID-19 new diagnostic guidelines - a message of reassurance from an internal medicine doctor in Shanghai. Swiss Med Wkly. 2020 Feb 24; 150: w20216. doi: 10.4414/smw.2020.20216. 
30. Bali S, Stewart KA, Pate MA. Long shadow of fear in an epidemic: fearonomic effects of Ebola on the private sector in Nigeria. BMJ Glob Health. 2016; 1(3): e000111. doi: 10.1136/bmjgh-2016000111

\section{Corresponding author}

Issara Siramaneerat can be contacted at: issara_sira@hotmail.com; issara_s@rmutt.ac.th
Perceptions, knowledge and self-defense behaviors

For instructions on how to order reprints of this article, please visit our website: www.emeraldgrouppublishing.com/licensing/reprints.htm Or contact us for further details: permissions@emeraldinsight.com 